\title{
A nemzeti kisebbségek parlamenti képviselete Európában, különös tekintettel a Jugoszláv utódállamokra Heka László*
}

\begin{abstract}
Az általunk vizsgált térségben némely kisebbségek részéröl hiányzik a nemzeti államhoz való politikai hüség, amelyet az államalkotó nemzet elvárna tölük, ezért is alakultak ki azok a sztereotípiák, amelyek szerint a nemzeti kisebbségek szeparatisták, föként olyan esetekben, ha az anyaországuk szomszédos állam. A korábbi három szocialista szövetségi állam - Jugoszlávia, Szovjetunió és Csehszlovákia felbomlása ezt részben bizonyitotta is, hiszen a délszláv államban sokéves véres háború folyt. $E$ három országból a népek önrendelkezési és elszakadási joga alapján 24 új utódállam keletkezett, amelyek nemzetközi elismerésének feltételei között szerepelt a nemzeti kisebbségek jogainak tiszteletben tartása. Jelen tanulmányban górcső alá vesszük a nemzeti kisebbségek parlamenti képviseletre vonatkozó szabályozását a posztjugoszláv országokban és annak kihatását a parlamenti képviseletükre és a társadalmi életre.
\end{abstract}

Kulcsszavak: nemzeti kisebbség-nemzetiség, parlamenti képviselet, népek önrendelkezési és elszakadási joga, függetlenségi népszavazás, kisebbségi jogok.

Parliamentary representation of national minorities in Europe, with special reference to the successor states of Yugoslavia

In this paper, we look at the regulation of the parliamentary representation of national minorities in postYugoslav countries and its impact on their representation in parliament and on social life.

Keywords: national minority-nationality, parliamentary representation, right of peoples to selfdetermination and secession, independence referendum, minority rights.

DOI: $10.32980 / M J S z .2021 .1 .939$

\section{A népek önrendelkezési és elszakadási joga}

posztjugoszláv államok nemzeti kisebbségi képviseletének bevezetése az 1991 Q és 1999 között zajló "balkáni konfliktusok” következménye. Az 1918-ban megalakult Szerb-Horvát-Szlovén Királyság utódjaként az 1945-ben megalakult szocialista Jugoszlávia hat köztársaságból és két autonóm tartományból álló szövetségi államként jött létre. A szövetségi és a köztársasági alkotmányokba átvették az önrendelkezési jog ún. lenini változatát, amely a tagállamoknak „biztosítja" az elszakadási jogot is.

\footnotetext{
* Habilitált egyetemi docens, Szegedi Tudományegyetem, Állam- és Jogtudományi Kar, Összehasonlító Jogi és Jogelméleti Intézet.
} 
A berlini fal leomlása napvilágra hozta az önrendelkezési jog átültetésének gondolatát, amely univerzálisan elfogadott politikai elv és a hatályos nemzetközi jog jelentős szabálya. ${ }^{1}$ Érvényesüléséhez földrajzilag elkülönített terület és valamilyen területi joghatóság szükségeltetik. Csakhogy a nemzetközi jog ma sem részletezi az eljárási szabályait, nem határozza meg az önrendelkezési jog alanyát (a nép, nemzet, emberek), valamint a jog terjedelmét sem, vagyis, hogy ki igényelheti, illetve ki nem jogosult erre. ${ }^{2}$ Emellett a nemzetközi jog garantálja minden ország számára a szuverenitást és a területi integritást, így alkotmányellenesnek és törvénytelennek tart minden olyan cselekményt, amely ezek ellen irányul. Márpedig az önrendelkezési jog érvényesítésénél pont ez történik. ${ }^{3}$ Emiatt a nevezett jog érvényesítése során szembe kerül az önrendelkezésre és elszakadásra való jog az állam szuverenitásának és területi integritásának jogával. Ez a jelenség pedig jelentős politikai és törvényhozási problémákat okoz a nemzetközi viszonyokban, és nem ritkán fegyveres összecsapásokhoz vezet.

A népek önrendelkezési és elszakadási jogának elvére való hivatkozásnak köszönhetően az elmúlt hetven évben négyszeresére nőtt a független államok száma a világon, és ez a folyamat tovább folytatódik. A volt Szovjetunió és Jugoszlávia 22 utódállamra bomlott szét (Csehszlovákiával együtt 24 új országra). Sok heves vitát okozott Koszovó 2008-ban történt elszakadása Szerbiától, valamint ennél is súlyosabb következményei voltak a Krím Ukrajnától való elszakadásának és az Orosz Föderációhoz való csatlakozásának, amely vélhetően nem az utolsó szeparáció. Közismertek a katalánok, baszkok, skótok, flamandok és vallonok ilyen irányú törekvései, illetve Quebec kanadai tartomány számos elszakadási kísérlete, vagy a bosznia-hercegovinai szerbek erre irányuló, kevéssé titkolt szándéka.

Az ENSZ Alapokmánya az 1. cikkely 2. §-ben az Egyesült Nemzetek céljai közül kiemeli „a nemzetek között a népeket megillető egyenjogúság és önrendelkezési jog elvének tiszteletben tartásán alapuló baráti kapcsolatok" fejlesztését, az 55. cikk pedig említést tesz "a nemzetek között a népeket megillető egyenjogúság és önrendelkezési jog elvének tiszteletben tartásán alapuló békés és baráti" kapcsolatokról. A két 1966-os emberi jogi egyezségokmány kimondja, hogy „minden népnek joga van az önrendelkezésre". 1960-ban az ENSZ 1514. sz. határozata megadta a nevezett elvnek a jogi kereteit, melyet Nyilatkozatként fogadott el az ENSZ Általános Közgyűlése 1960. december 14-én.

Ekkor kapott először ez az alapelv jogi státuszt, és jóllehet nem volt kötelező ereje, mégis a nemzetközi jog imperatív normájává (jus cogens) vált. Az 1541. sz. határozat definiálta, hogy az ENSZ Alapokmánya garantálja az emancipációt azon területek számára, melyek „földrajzilag elkülönítettek, etnikailag és/vagy kulturálisan

\footnotetext{
${ }^{1}$ Vladimir Ibler: Pravo naroda na samoodređenje i zloupotreba tog prava. In: Politička misao, Vol.29. No.2. Zagreb 1992. 54. p. http://hrcak.srce.hr/index.php?show=clanak\&id_clanak_jezik=166848 (letöltve: 2021. március 19.).

2 U. o.

${ }^{3}$ Heka László: A népek önrendelkezési és elszakadási jogának megvalósítása a volt Jugoszlávia felbomlása esetében. In: Blutman László (szerk.). Ünnepi kötet Dr. Bodnár László egyetemi tanár 70. születésnapjára. Szegedi Tudományegyetem Állam- és Jogtudományi Kar, Szeged: 2014. pp. 161-174.
} 
mások attól az államtól, melynek irányitása alá tartoznak".4 Ezen alapulva történhetett meg a dekolonizáció, amelynek keretében az önkormányzattal nem rendelkező területek jogot kaptak arra, hogy létrehozzák független államukat, vagy egyesüljenek más országgal, illetve csatlakozzanak más államhoz. Ebből kiindulva egyesek azt tartják, hogy az önrendelkezési jog csak a gyarmatokat illette, és nem bármelyik más területen élő etnikumokat, nyelvi stb. csoportokat. ${ }^{5}$

Elfogadott, hogy a fenti jog fennállása nélkül nincs valódi demokrácia, így John Stuart Mill a nemzeti önrendelkezést tekintette a politikai szabadság előfeltételének, mondván, hogy a nemzetállam megvalósítja a demokráciát, a demokrácia pedig megvalósítja a nemzetállamot. ${ }^{6}$

Mára a fenti jog a nemzetközi szokásjog normája, amely kapcsán a Nemzetközi Bíróság 1995-ben megállapította: "a népek önrendelkezési joga, ahogyan az az Alapokmányból ered és az ENSZ gyakorlata alapján kifejlődött, egy erga omnes szembeszegezhetö jog". A Bíróság joggyakorlata is elismerte, hogy "a mai nemzetközi jog egyik lényegi elvéról van szó".

Az egykori Jugoszlávia területén sem a szövetségi, sem a tagállami alkotmány egyáltalán nem rendelkezett a preambulumban rögzített jog érvényesítésének eljárásáról. A népszuverenitás elvéből kiindulva a népszavazást tartották a leginkább demokratikus megoldásnak, így Szlovéniában 1990. december 23-án, míg Horvátországban pedig 1991. május 19-én tartották meg a függetlenségi népszavazást. ${ }^{8}$ Szlovéniában a választópolgárok 88,5 százaléka voksolt, közülük majd $95 \%$ a függetlenség mellett »tört lándzsát«, míg Horvátországban a szavazópolgárok 83,56 százaléka adta le voksát, kik közül 93,24 \% a függetlenségre szavazott. ${ }^{9}$ Ezután a két ország 1991 . június 25 -én külön deklarációban kiáltotta ki függetlenségét. ${ }^{10}$

4 Bojan Gavrilović:Istorija prava na samoopredeljenje. (http://bgcentar.org.rs/bgcentar/wpcontent/uploads/2013/11/Istorija-prava-na-samoopredeljenje.pdf (letöltve: 2014. március 7.), 2013, 8. p.

${ }^{5}$ Malcolm N. Shaw: Peoples, Territorialism and Boundaries, European Journal of International Law (1997) 8(3) 481. p. http://www.ejil.org/pdfs/8/3/1457.pdf, Közli Gavrilović i. m. 9. p.

${ }^{6}$ John S. Mill: Consideration on Representative Government. Liberal Art Press, Indianapolis 1958. 229237. pp., közli Benyamin Neuberger: Nemzeti önrendelkezés: egy fogalom dilemmái. Magyar Kisebbség. 2000/3. (21.). sz. 140.

p. http://www.jakabffy.ro/magyarkisebbseg/index.php?action=cimek\&cikk=m000310.html.

${ }^{7}$ Nguyen Quoc Dinh et al.: Nemzetközi közjog. Osiris Kiadó, Budapest,1997, 251. p.

${ }^{8}$ Izid glasovanja na plebiscitu za samostojnost in neodvisnost Republike Slovenije 23. 12. 1990. Results of voting at the plebiscite on sovereignity and independence of the Republic of Slovenia 23. december 1990. http://www.stat.si/letopis/2011/05_11/05-11-11.htm (letöltve: 2014. május 22.). In: Statistični letopis 2011 [Statistical Yearbook 2011]. Statistical Yearbook 201115 (Statistical Office of the Republic of Slovenia). 2011. p. 108.

9 Izvješće o provedenom referendumu u Republici Hrvatskoj Republičke komisije za provedbu $\begin{array}{lllll}\text { referenduma od } 22 . & \text { svibnja } & 1991 . & \text { godine. }\end{array}$ http://www.izbori.hr/arhiva/pdf/1991/1991_Rezultati_Referendum.pdf (letöltve: 2014. május 22.).

${ }^{10}$ A szerző a Pélmonostori Járás (akkoriban az 54 ezer lelket számláló horvátországi Baranya egy közigazgatási egységet - járást képezett) öttagú Választóbizottságának tagjaként az ország első többpárti választásnak és a függetlenségi népszavazásnak aktív résztvevője volt (1990-91-ben). A Drávaszögnek nevezett terület jelentős mértékben magyar ajkú, ezért az öttagú, jogászokból álló bizottságnak a két horvát (az egyik elnök), és két szerb (az egyik alelnök) tagja mellett magyar tagként vett részt. 
A szerb-montenegrói politikai elit és a jogászprofesszorok álláspontja szerint azonban a népszavazás kírására való jog a Jugoszláviát alkotó nemzeteket (az ország bármelyik részében is élnek) illette, és nem pedig a köztársaságokat. ${ }^{11}$ Emiatt Horvátországban a helyi szerbek megtartották a népszavazást a maguk számára, majd a szövetségi hadsereg és a szerbiai önkéntesek támogatásával megszállták az általuk "kirajzolt" területeket. ${ }^{12}$ Ez a forgatókönyv ezután megismétlődött a multietnikus és multikonfesszionális Bosznia-Hercegovinában is.

Bosznia-Hercegovinában 1992. február 29-én és március 1-jén tartották meg az országos népszavazást, amelyen zömében bosnyákok és horvátok vettek részt. Ezen részt vett az ország lakosságának 64,31\%-a, akik közül 99,44 \% a függetlenség mellett voksolt. ${ }^{13}$ A népszavazás eredményei alapján az ország március 1-jén kiáltotta ki az önállóságot. Válaszként a szerbek ostrom alá vették Szarajevót és a többi bosznia-hercegovinai várost, mire 1995-ig elhúzódó háború robbant ki.

Az Európai Közösség (EK) és számos más ország 1992. január 15-én ismerte el Szlovénia és Horvátország függetlenségét, majd az ENSZ-be is felvételt nyertek. Bosznia-Hercegovina függetlenségét az EK 1992. április 6-án, az USA pedig egy nappal később ismerte el, majd május 22-én az ország az ENSZ tagja lett. Az akkori Macedónia (ma Észak-Macedónia) 1991. szeptember 8-án megtartott népszavazást követően kikiáltotta a függetlenségét, de Görögország kifogásolta az ország nevét, ezért Macedónia Volt Jugoszláv Köztársaság (Former Yugoslav Republic of Macedonia) elnevezéssel csak 1995-ben lett az ENSZ tagja. ${ }^{14}$

Montenegróban is megtartották a referendumot 1992. március 1 -jén, de a lakosság zöme a Szerbia melletti maradásra voksolt (a 421.549 választópolgárból Szavazott $278.382(66,04 \%)$ polgár, kik közül 266.273 (95,65\%) a Jugoszláviában való maradás melllett döntött). Csupán Szerbia nem kérdezte meg lakosait, hogyan képzelik el jövőjüket. Szerbia és Montenegró 1992. április 27-én hozta létre a Jugoszláv Szövetségi Köztársaságot (Savezna Republika Jugoslavija) ${ }^{15}$, amelyet

${ }^{11}$ Heka László: A szláv államok jogrendszerei. JATEPress, Szeged, 2008. 90. p., 15. ij.; U. ő.: Etnikai, vallási és politikai konfliktusok a Balkán térségében. II. rész: Társadalmi, etnikai, vallási és politikai viszonyok a Bakán térségben III. rész: A konfliktusok kialakulása [221pp.]. A Pólay Elemér Alapítvány tansegédletei. Szeged, 2010. 202. p. 505. lj.

12 Izvještaj o provođenju izjašnjavanja srpskog naroda u RH o srpskoj autonomiji. Centralna komisija za provođenje izjašnjavanja, Srb, 30. rujna 1990., HMDCDR, 2, kut. 359. Közli: Ante Nazor: Odluka o prisajedinjenju SAO Krajine Republici Srbiji. In: Hrvatski vojnik, br. 280. veljača, 2010. http://www.hrvatski-vojnik.hr/hrvatski-vojnik/2802010/domovinskirat.aspte (letöltve: 2014. május 22.)

${ }^{13}$ Rezultati republičkog referenduma za utvrđivanje statusa Bosne i Hercegovine koji je održan 29. februara i 1. marta 1992. godine. Republička izborna komisija, 6. marta 1992. godine. Službeni list $\mathrm{RBiH}$, br. 7. 27. mart 1992. godine http://afanovblog.blogspot.hu/2013/03/dan-nezavisnostidokumenti-referenduma.html (Letöltve: 2014. május 22.); Konačni rezultati referenduma u $\mathrm{BiH}$ (Sarajevo, 9. 3. 1992.) Forrás: HINA, Baza EVA, Vijest HNA3090111:1, 09.03.1992.

14 Macedóniában a választójoggal rendelkező lakosság 75,74 \%-a vagyis 1.132 .981 fő vett részt a referendumon. Közülük $96.46 \%$, vagyis az összlakosság 72,16 \%-a a függetlenségre voksolt. Републичка изборна комисија „Извештај за спроведувањето и резултатот од претходното изјаснување на граѓаните на Република Македонија на референдумот одржан на 8 септември 1991 година", 2 стр.

http://www.sec.mk/arhiva/1990_Referendum/Izvestaj_za_sproveden_referendum_1990.pdf (Letöltve: 2014. március 31.).

15 Szabó Zsolt: Jugoszlávia: „a délszláv állam” 85 éve - közjogi fejlődés, integráció és dezintegráció. In: Jogtörténeti szemle. Budapest, 2018. 1-2. szám, 78-83. p., 81. p. 
2003-ban Szerbia és Montenegró uniójának nevezték át. Három évvel később Montenegró a május 21-ei népszavazás után hirdette ki a függetlenségét. ${ }^{16}$ Ezzel Szerbia magára maradt és önálló állammá vált. Végül 2008. február 17-én Koszovó is elszakadt Belgrádtól és kikiáltotta függetlenségét, melyet eddig több mint száz állam ismert el.

A délszláv állam felbomlásával kapcsolatosan felmerült jogi kérdések eldöntése érdekében az Európai Közösség „rendkívüli miniszteri értekezlete" 1991. augusztus 27-én létrehozott egy ad hoc jellegü Választott Bíróságot, amely az Európai Konferencia Jugoszlávia békéjéért címú intézmény mellett tevékenykedett. A francia alkotmánybíróság elnöke, Robert Badinter vezetése alatt múködő testület elfogadta azt az álláspontot, amely szerint az önrendelkezési jog a jugoszláv tagköztársaságokat illeti, így az 1991-92-ben megtartott népszavazások feljogosították őket a függetlenség kimondásához. ${ }^{17}$ A jogutódlás kapcsán a Választott Bíróság 1992-ben megállapította, hogy „Jugoszlávia felbomlott és már nem létezik", majd az ENSZ Biztonsági Tanácsa felszólította a jogutódlásban érdekelt Szerbia és Montenegrót (akkor még egy államot alkottak), hogy nyújtsa be az ENSZ tagfelvételre irányuló kérelmét.

Az ENSZ BT 1991. szeptember 25-ei 713. sz. határozata, valamint az 1992. május 15-ei 752. sz. határozata ugyan kimondta, hogy semmilyen erőszakkal történő területi nyereség, illetve változás sem ismerhető el. Azt azonban mégis jelezte, hogy a horvátországi és bosznia-hercegovinai szerbeket megilleti az állampolgárság megválasztásának a joga és a kisebbségvédelem. ${ }^{18}$ Emiatt elvárta az új országoktól, hogy alkotmányaikban garantálják mindezeket.

\section{A háború(k) következményei - kisebbségvédelem}

A nemzetközi elismerés pillanatában Horvátország egyharmadát és BoszniaHercegovina területének bő kétharmadát megszállás alatt tartották, a "Krajina” területére pedig az ENSZ nemzetközi békefenntartó erői érkeztek. A békét végül a horvát fegyveres erők 1995-ben lefolytatott két (májusi és augusztusi) hadmúveletét követően megkötött daytoni békeszerződést hozta meg. ${ }^{19}$ Bosznia-Hercegovina

${ }^{16}$ A 484.718 választópolgárból szavazott 419.236, vagyis 86,49\%. Ezek közül 230.711 fő (55,5 \%) a függetlenségre voksolt, 184.954 fö $(44,5 \%)$ pedig ellene. Konačni rezultati referenduma o državnopravnom statusu Republike Crne Gore. Republička komisija za sprovođenje referenduma komisija, 31. maja 2006. Službeni list Republike Crne Gore, br. 35. Podgorica, 31. maja 2006. 10211022. p. http://www.snpcg.org/5-3.izvjestaji1-\%20983-1024.pdf (letöltve: 2014. május 22.).

17 Erröl lásd Roland Rich: Recognition of States: The Collapse of Yugoslavia and the Soviet Union. http://ejil.oxfordjournals.org/journal/Vol 4/No1/art4.pdf. Vö. Alain Pellett: The Opinions of the Badinter Arbitration Committee: A second Breath for the Self-determination of Peoples. European Journal of International Law. Vol. 3. 1. 1992, 179.p.

${ }^{18}$ Uo. 263. p.

19 1995. július 11-én a boszniai szerbek elfoglalták a kéksisakosok által védett bosznia-hercegovinai Srebrenicát, majd nyolc nap múlva a szintén az ENSZ által „védett” Žepát is. A srebrenicai mészárlás és a Bihać elleni egyre fokozódó támadásokat követően július 22-én Splitben megkötötték a horvátbosnyák katonai egyezményt, és közös akciót indítottak Bihać felmentésére. A nagyhatalmak hallgatólag beleegyeztek ebbe, így miután augusztus 4-én és 5-én a Vihar (Oluja) nevű felszabadító akció során a 
kénytelen volt elismerni a Szerbek Köztársaságát mint a két entitás egyikét BoszniaHercegovina Föderációja mellett, az ottani szerbek pedig elfogadták Szarajevót fóvárosuknak.

Az entitások a valóságban szinte államok lettek az államban, hiszen külön elnökük kormányuk, alkotmánybíróságuk, igazságszolgáltatásuk, közigazgatásuk stb. van, ami jelentősen megnehezíti az ország működőképességét. ${ }^{20} 1998$. január 15-én Kelet-Szlavónia, Baranya és Nyugat-Szerémség békés úton visszakerült Horvátországhoz, aminek következtében az ENSZ erők elhagyhatták a térséget, a horvátországi szerbek pedig nagy számban elmenekültek többnyire Szerbiába és Bosznia-Hercegovinába. Jelenleg 4,5\%-ra csökkent a Horvátországban elő szerbek számaránya, 1991-ben pedig még 600 ezren (12,2\%) voltak Horvátországban.

A háború következtében jelentősen megváltozott az egész térség, főként BoszniaHercegovina etnikai összetétele. A népszámlálási adatok arról is tanúskodnak, hogy az utódállamok közötti "lakosságcsere" mellett 1991 és 1999 között a volt Jugoszlávia területéről több százezer ember külföldre emigrált. ${ }^{21} \mathrm{~A}$ régióban az utolsó konfliktusra a mai Észak-Macedóniában került sor 2001-ben, de ez nem a függetlenség kikiáltásához köthető. Tulajdonképpen a macedón kormányzat és a lakosság egyharamadát kitevő albánok közötti fegyveres összecsapás volt, amelynek következménye az albán kisebbség jogainak kiszélesítése lett.

A fenti események ösztönözték a nemzetközi közösséget arra, hogy az újonnan létrehozott posztjugoszláv államokat a kisebbségi jogok teljes körú betartására kötelezze. Ez nem csak a nemzetközi egyezmények elfogadására tért ki, hanem Horvátországban például még a közkegyelem kihirdetésére is. A horvát parlament (Sabor) ugyanis 1996-ban elfogadott törvényével közkegyelemben részesíti az 1991ben kirobbant lázadással kapcsolatos valamennyi büncselekmény elkövetőit, kivéve a háborús bűnösöket. ${ }^{22}$

Emellett Horvátország vállalta a kisebbségek parlamenti mandátumának biztosítását is, így olyan személyek kerülhettek a politikai életbe, akik korábban fegyverrel szálltak szembe az adott ország függetlenségi törekvéseivel. Egyesek közülük parlamenti képviselők lettek, ami főleg a háborús veteránok körében ellenséges felhangokat váltott ki a kisebbségek parlamenti képviseletével szemben.

Más délszláv országok is ambivalens viszonyt táplálnak azokkal a nemzeti kisebbségekkel szemben, amelyek tagjai megtagadták az állam iránti hűséget. Ezért alkotmányaikban kizárják a területi autonómia lehetőségét (kivéve Szerbiát),

horvátok visszafoglalták az egykori „Krajina” területét, ezután a horvát seregek Bosznia-Hercegovina megsegítésére indultak. Ott a horvát és bosnyák csapatok visszaszerezték az ország területének közel $20 \%$-át és utat nyitottak a daytoni béke megkötéséhez.

${ }^{20}$ Ustav Federacije Bosne i Hercegovine "Službene novine Federacije BiH" broj 1/94.

${ }^{21}$ Erről lásd bővebben Szondi Ildikó: Nemzetiségi demográfiai viszonyok a déli szláv országokban. Pólay Elemér Alapítvány, Szeged, 2007.

22 A nemzetközi közösség nyomására elfogadott törvény közkegyelmet hirdetett minden horvát állampolgár számára, aki részt vett „az 1990. augusztus 17. és 1996. augusztus 23. között a Horvátország elleni lázadásban", ha nem követett el háborús búnt, népirtást, illetve terrorizmussal kapcsolatos büncselekményt. Lásd Osnovni krivični zakonik Republike Hrvatske "Narodne novine" broj 31/93. - pročišćeni tekst, 35/93., 108/95., 16/96. i 28/96. 123.-137. §. 
helyette a kisebbségeknek személyi és kulturális autonómiát garantálnak beleértve az egyéni és a kollektív jogokat. ${ }^{23}$

\section{Nemzetiségek parlamenti képviselete ${ }^{24}$}

A nemzeti kisebbségek parlamenti képviseletével kapcsolatosan Európa különböző államai eltérő megoldásokat alkalmaznak. Az egyik létező koncepció az, hogy a nemzetiségen alapuló parlamenti képviselet nem annyira a politikai célok kifejezésére irányul, hanem az adott nemzeti kisebbség jogainak és érdekeinek védelmére. Ebből kifolyólag e nézetet vallók úgy tartják, hogy a nemzeti kisebbségek parlamenti képviseletének nem szabadna politikai töltetúvé válnia, csakhogy az országgyűlési képviselő intézménye elválaszthatatlan a politikától.

Az alkotmányok rendszerint rögzítik, hogy a képviselőket "a választópolgárok általános és egyenlő választójog alapján, közvetlen és titkos szavazással, a választók akaratának szabad kifejezését biztosító választáson, sarkalatos törvényben meghatározott módon választják", valamint, hogy "az országgyűlési képviselők jogai és kötelezettségei egyenlők, tevékenységüket a köz érdekében végzik, e tekintetben nem utasíthatók." 25 Ebből kiindulva az következik, hogy nem tehető különbség a megválasztott honatyák között az alapján, hogy valaki az államalkotó nemzet vagy egy adott nemzeti kisebbség tagja-e. Emiatt ha az ország nem kíván a kisebbségieknek ilyen hatáskört biztosítani, akkor az érdekképviseletüket más módon próbálja megoldani.

A górcső alá vett országok közül Horvátországban külön törvény szabályozza a kisebbségiek jogait. ${ }^{26}$ Ezek közül legfontosabb a parlamenti képviseleti jog, valamint az alkotmány 15. §-ának rendelkezése, amely szerint az országgyülés (Sabor) a nemzeti kisebbségek jogait szabályozó sarkalatos (organikus) törvényeket valamennyi képviselőjének kétharmados szavazattöbbségével fogadja el. ${ }^{27}$

A Saborba megválasztandó képviselők számáról nem az alkotmány rendelkezik, hanem annak meghatározását a választási törvényre bízza. Az alkotmány csupán megjelöli a honatyák minimális és maximális számát („100 és 160 között”). Az ilyen megoldás rugalmasságot biztosít arra az esetre, ha jelentősen megnőne a lakosság

\footnotetext{
${ }^{23}$ Ustav Republike Hrvatske (pročišćeni tekst). Narodne novine« br. 56/90, 135/97, 8/98 - pročišćeni tekst, $113 / 2000,124 / 2000$ - pročišćeni tekst, 28/01, 55/01, 76/10, 85/10 és 5/14. http://narodnenovine.nn.hr/clanci/sluzbeni/2010_07_85_2422.html. Letöltve: 2014. VII. 7. Članak 10.; Устав Републике Србије "Службени гласник Републике Србије" 98/06. Члан 13.; Устав на Република Македонија „Službeni vesnik na Republika Makedonija”1/1992, 31/1998 és 91/2001), Член 49.

${ }^{24}$ Országgyűlés Hivatala Közgyűjteményi és Közművelődési Igazgatóság Képviselői Információs Szolgálat 2017/20. 2017. április 7. Készítette: Vajda Adrienn - Képviselői Információs Szolgálat. Internet: https://www.parlament.hu/documents/10181/1202209/Infojegyzet_2017_20_nemzetisegek_parlamen ti_kepviselete.pdf/26869007-1838-46ac-a0a2-835e8b9a5110. Letöltve: 2019. december 21.

${ }^{25}$ Magyar Alaptörvény. Magyar Közlöny 43. szám, 2011. április 25. http://www.alkotmany.hu/. Lásd még: Heka, László: Ustavnopravni poredak Mađarske u svjetlu Ustava iz 2011. godine. Pravni vjesnik Osijek br 3-4., Osijek 2013. str. 157-185. http://vjesnik.pravos.hr/preuzimanje/2013-3_4.pdf

${ }^{26}$ Ustavni zakon o pravima nacionalnih manjina. Narodne novine broj 155/2002.

27 Lásd Zakon o izborima zastupnika u Hrvatski sabor. Pročišćeni tekst. "Narodne novine”, br. 69/03. Članak 15.
} 
vagy a választópolgárok száma. A Balkánon az észak-macedón („120 és 140 között”), a görög („200-tól 300-ig") és a román alkotmány („,a képviselők és a szenátorok számát a választási törvény az ország lakosságához viszonyítva állapítja meg" - 62. §) rendelkeznek így, a legtöbb ország viszont az alkotmányokban határozza meg a képviselők számát.

Mint említettük a nemzeti kisebbségek (elsősorban a szerbek) jogait garantáló horvát alkotmányos törvény megalkotása a háborút követően a "nemzetközi közösséggel" való egyeztetés eredménye lett. ${ }^{28} \mathrm{~A}$ nemzeti kisebbségek parlamenti képviseletre való joga független a kisebbségiek számától. Nyolc képviselőt választanak, mégpedig hármat a szerbek, egyet-egyet a magyarok és az olaszok, egyet közösen a csehek és a szlovákok, a további kettő közül az egyiket az osztrák, a bolgár, a német, a lengyel, a roma, a román, a ruszin, a török, az ukrán, a vláh és a zsidó nemzetiségúek, a másodikat pedig az albán, a bosnyák, a montenegrói, a macedón és a szlovén kisebbség tagjai.

Jelenleg 151 képviselő alkotja a parlamentet Horvátországban. A törvény értelmében az országot tíz választókerületre osztották, melyek mindegyikében 14 képviselőt választanak (összesen 140 föt). A XI. választókörzetben a külhoni horvátok választanak három országgyűlési képviselőt. A 2016. évi választásokon, 112 választási helyen mindössze 21.223 fő szavazott, ebből 21.208 érvényesen. A kormányzó HDZ 13.117 szavazattal (62,72\%-kal) kettő, Željko Glasnović függetlenek listája (Neovisna lista - Željko Glasnović) 5.211 vokssal (24,91\%-kal) egy mandátumhoz jutott. 2020-ban ismét kiemelkedő eredményt ért el a HDZ, így mindhárom mandátumot elnyerte.

Nem volt magasabb a részvétel a XII. választókörzetben választandó nemzetiségi képviselők megválasztása iránt sem. A 211.267 szavazatra jogosult választópolgár közül mindössze 37.957 (17,97\%) fő járult a 6574 választóhely valamelyikében az urnákhoz és megválasztotta a nyolc kisebbségi képviselőt. $A 138.539$ választásra jogosult szerb nemzetiségü állampolgár közül csak 19.561 (14,12\%) fő szavazott és a szerb kisebbség soraiból három parlamenti képviselőt választott. Valamennyien az Önálló Demokratikus Szerb Párt (Samostalna demokratska srpska stranka) tagjai. A magyar kisebbség soraiból 9.981 állampolgár volt jogosult szavazni. Az urnához 5.213 fő $(52,23 \%)$ járult és a két jelölt közül 2.731 (53,02\%) szavazattal megválasztotta Jankovics Róbertet, a Horvátországi Magyarok Demokratikus Közössége (HMDK) jelöltjét. Az ellenjelölt Juhász Sándor 2.420 (46,98\%) szavazatot kapott.

A 11.440 szavazatra jogosult olasz kisebbség soraiból 2.338 (20,44\%) fó szavazott. Közülük az immár veteránnak számító (1992 óta képviselői mandátummal bíró) Furio Radin 1.676 (72,65\%) szavazatot szerzett. A kisebbségi képviseletet bírálók leginkább az ő példáját emelik ki.

A cseh és a szlovák kisebbség 6.763 választásra jogosult állampolgára közül 1.591 (23,53\%) fó szavazott a két jelölt egyikére. A cseh Vladimir Bilek 1.329 (84,43\%) szavazattal nyerte meg a választásokat. A cseh jelölt így Radinnál is kevesebb

\footnotetext{
${ }^{28}$ Ustavni zakon o pravima nacionalnih manjina (Narodne novine br. 155/02, 47/10, 80/10, 93/11).
} 
szavazatot kapott, mivel a cseh-szlovák kisebbség sokkal kisebb létszámú, mint az olasz.

Az osztrák, a bolgár, a német, a lengyel, a roma, a román, a ruszin, a török, az ukrán, a vláh és a zsidó nemzetiségủek szavazói száma 14.767 fó, akik közül mindössze 3.847 választópolgár $(26,05 \%)$ voksolt. Képviselő lett a roma Veljko Kajtazi is $2.010(53,16 \%)$ szavazattal. Végül a 29.777 választópolgárt számláló albán, bosnyák, montenegrói, macedón és szlovén kisebbség soraiból a megjelent $5.407(18,16 \%)$ szavazó az albán Ermina Lekaj Prljaskaj választotta meg képviselőnek $1.354(25,31 \%)$ szavazattal.

A fenti adatokból kitúnik, hogy csak a magyarok körében érte el a részvételi arány (52,23\%) az országos szintet $(52,59 \%)$, a többi kisebbség esetében az messze elmaradt az átlagtól, leginkább a szerbek körében, ahol a részvétel mindössze $14,12 \%$ volt. A 2020 -as választásokon ugyanezeket a képviselőket választották meg. A szerbek közül Milorad Pupovac 10.732, Dragana Jeckov 8.375, Boris Milošević pedig 7.712 szavazatot kapott. A magyarok képviselője ismét Jankovics Róbert lett 2.807 vokssal, az olaszoké Furio Radin 888-cal, míg a többi nemzetet képviselő Vladimir Bileket 1.514-gyel, Veljko Kajtazit 3.649-cel és Ermina Lekaj Prljaskaj 1.708 szavazattal képviselik.

Horvátország mellett egyedül Szlovénia garantálja az országgyűlési mandátumot a nemzeti kisebbségek számára. A horvátoktól eltérően, azonban északnyugati szomszédaik ezt a jogot mindössze két kisebbség - az olasz és a magyar - számára biztosítják és nem az ezeknél népesebb szerb, illetve horvát nemzetiség részére. Ezt azzal indokolják, hogy az alkotmányban az olasz és a magyar nemzetiséget őshonosnak deklarálták. Emiatt az általuk lakott településeken a szlovén mellett hivatalos nyelv a magyar, illetve az olasz, valamint a két nemzetiség egy-egy parlamenti képviselő delegálására is jogosult. ${ }^{29}$

A két kisebbség jogosult a saját nemzeti szimbólumok használatára, az anyanyelvi oktatásra, a nemzeti identitás ápolására, szervezetek létrehozására, tudományos és egyéb tevékenység folytatására, az anyaországgal való kapcsolatok fenntartására. Azok a törvények, jogszabályok és általános szabályzatok, amelyek csak a nemzeti kisebbségek alkotmányban megállapított jogaira és helyzetére vonatkoznak, nem fogadhatók el a nemzeti közösségek képviselőinek beleegyezése nélkül. A Szlovén Köztársaság külön törvényben szabályozza a roma közösség helyzetét és jogait is. ${ }^{30}$ Az ország törvényhozó szerve a kétkamarás parlament, amely a Nemzetgyűlésből és a Nemzeti Tanácsból áll. ${ }^{31}$ A 90 fös Nemzetgyülés magyar és olasz kisebbségi képviselőjét általános, egyenlő, közvetlen és titkos választásokon négy évre választják meg a szlovén állampolgárok. ${ }^{32}$ A 2000. évi alkotmánymódosítás elöírta,

\footnotetext{
${ }^{29}$ Ustava Republike Slovenije Uradni list RS, št. 33/91-I, 42/97, 66/2000 in 24/03. 11. člen.

${ }^{30}$ Zakon o romski skupnosti v Republiki Sloveniji. /ZRomS-1/ (Ur.I. RS, št. 33/2007. Lásd bővebben Roman Lavtar: Temeljne pravice: Romi in enakost pred zakonom. Pravna praksa Ljubljana, št. 1/2005.

${ }^{31}$ A szlovén felsőház a 40 tagú Államtanács (Državni svet), amelynek 4-4 tagja a munkaadókat, a munkavállalókat és a földműveseket, iparosokat képviseli, hat tag a mezőgazdaságban dolgozókat, 22 pedig a helyi érdekeket. Zakon o državnem svetu /ZDSve/ (Ur.I. RS, št. 44/1992, 11/2003 SkI.US: U-I417/02-7, 73/2003 Odl.US: U-I-346/02-13, 76/2005).

32 Zakon o določitvi volilnih enot za volitve poslancev $v$ državni zbor /ZDVEDZ/ (Ur.I. RS, št. 46/1992, 80/2004). Lásd Szlovénia alkotmánya. 80. člen..
} 
hogy a képviselőket - a kisebbségi képviselők kivételével - az arányos képviselet elvének figyelembevételével választják, azzal, hogy a négy százalékos küszöb elérése szükséges. ${ }^{33} \mathrm{~A}$ mentelmi jogot élvező honatyák az egész nép képviselői, őket semmilyen utasítás nem köti (82. §).

A legutóbbi - előrehozott - 2018. június 3-ai választásokon tizenegy választókerületben nyolc-nyolc képviselőt (összesen 88 főt) választottak, illetve a maradék két mandátumot a magyar és az olasz kisebbség adja. Az őshonos kisebbségek képviselőit a pontozáson alapuló úgynevezett Borda-rendszer alapján választják. A két kisebbség közül a magyar valamivel népesebb (a 2001 évi népszámlálás 6200 magyar ajkú szlovén állampolgárt jegyzett fel). A 3.043 (51,97\%) magyar nemzetiségűek által leadott voksból 42 érvénytelen volt. Az új képviselő a Muravidéki Magyar Önkormányzati Nemzeti Közösség Tanácsának elnöke Horváth Ferenc lett, akit 1.876 szavazópolgár tett az első helyre, ami 3.752 pontot jelentett, míg 374 szavazó a második helyre, ami további 374 pontot jelentett. Összes pontszáma 4.193 vagyis 60,32\%. Ellenfele Sobočan Gabriela 1.047 első helyezést szerzett, ami 2.094 pontot jelentett, emellett 620 pontot szerzett másodikként is, ami összesen 2.772 pontot vagyis $39,68 \%$-ot tett ki.

Az olaszok közötti képviselóválasztáson 1486 szavaztak, 1464-en érvényesen. Megválasztott lett Felice Ziža 2570 ponttal. ${ }^{34}$ A magyarok képviselője Horváth Ferenc megválasztása után a sajtónak elmondta: „Nemzetiségi képviselőként nem szeretnék a mérleg nyelve lenni, vagyis biztosan nem én adom a 46 . szavazatot a kormányalakításhoz." ${ }^{\prime 35}$ Jóllehet a szlovén kisebbségvédelem példaértékű nemzetközi szinten, mégis Horváth Ferenc 2019-ben a szlovén politikai élet központi alakjává vált. Májusban a Szlovén Korrupcióellenes Bizottság (KPK) összeférhetetlenség miatt felhívta az országgyülési képviselőt, hogy záros határidőn belül a két posztjának valamelyikéről mondjon le. Horváth Ferenc ezt visszautasította, mivel e megkötésről egyetlen jogszabály sem rendelkezik.

Ezután a Muravidéki Magyar Önkormányzati Nemzeti Közösség (MMÖNK) rendkívüli ülésén támogatta elnökük döntését. Az ellene irányuló támadások hátterében egyesek a Muravidék Szlovéniához való csatolásának 100. évfordulójával kapcsolatos álláspontokat sejtik, ${ }^{36}$ mások viszont úgy tartják, hogy a szlovének egy része amiatt neheztel, mert a szlovéniai nemzetiségi képviselő tagja a Kárpátmedencei Magyar Képviselők Fórumának (éppúgy, mint horvátországi kollégája). Ez a testület 2004-ben jött létre mint a magyar Országgyülés munkáját segítő tanácsadó intézmény. ${ }^{37}$

33 Szlovénia alkotmánya. Dopolnitev. 80. člen. Dopolnjen leta 2000. „Uradni list Republike Slovenije” broj 66/2000).

${ }^{34}$ Republika Slovenija Državna volilna komisija. https://dvk-rs.si/arhivi/dz2018/\#/rezultati Letöltve: 2020. I. 13.

35 Illés Gergő: Megerősödött a magyarságtudatunk - Szlovénia magyar képviselője a Mandinernek. In: Mandiner, 2018. VI.

07. https://mandiner.hu/cikk/20180607_horvath_ferenc_szlovenia_magyar_kepviseloje_interju

${ }^{36}$ Danica Ksela: 'Pritisk poslanca na dvojezične osnovne šole in vrtce ni dopusten'. Novice. Murska Sobota. 2019. 05. 19. https://www.24ur.com/novice/slovenija/horvath.html.

${ }^{37}$ Ismertető. https://www.parlament.hu/ismerteto. Letöltve: 2020. I. 13. 
Bosznia-Hercegovina helyzete egyedülálló, hiszen az alkotmányát nem a parlament alkotta, hanem a daytoni békeegyezmény szerves része. A szerb Slobodan Milošević, a horvát Franjo Tuđman és a bosnyák elnök Alija Izetbegović írák alá a békeszerződést és fogadták el az ország alkotmányát, amelyet az amerikai jogászok fogalmazta meg. Ezért az alkotmány - legalábbis külsőleg - az angolszász mintákra hasonlít, és nem sorolható a kontinentális jog típusába tartozó többi posztjugoszláv állam alapokmánya közé. Bosznia-Hercegovina Belgiumhoz és Ciprushoz hasonló kivételes alkotmányos konstrukciót képez, olyat, amely a politikai és etnikai ellentétek, illetve a háborús események következményeként jött létre.

A többi országtól különbözik a jogrendje abban is, hogy három államalkotó nemzetet ismer, és valamennyi jogot a bosnyák, a szerb és a horvát nemzetiségü állampolgáraira ruházza. Az ország élén az egy bosnyák, egy szerb és egy horvát elnökből álló elnökség áll. A törvényhozó testület a Parlamentáris Közgyülés, amelynek két háza van: a Népek Háza, és a Képviselőház. Az előbbi 15 delegátusból áll, minden államalkotó nemzet öt küldöttet választ a soraiból, méghozzá a bosnyák és a horvát képviselőket a Föderáció Népei, a szerb képviselőket pedig az RS Népgyűlése választja. A Népek Háza határozatképes, ha kilenc tag jelen van, de legalább három bosnyák, három horvát és három szerb képviselő. ${ }^{38}$ A 42 képviselőből álló Képviselőházban egyforma számban (14-14) kapnak helyet a bosnyák, a horvát és a szerb nemzet képviselői, akiket közvetlenül választanak meg a saját entitásukban. (Tehát kétharmadukat a bosnyák-horvát föderációban, egyharmadukat pedig a szerbek képviselőtestületében). A szavazattöbbséghez elegendő a jelenlévő képviselők egyszerü többsége.

Az alapokmány egy bonyolult decentralizált politikai rendszert szabályoz, amely politikai sztenderdként a nemzeti hovatartozást írja elő, így a különböző tisztségeket a valamely államalkotó nemzethez való tartozás alapján lehetséges betölteni. Ez a megoldás ugyan a kisebbségek széles körü jogvédelmét garantálja, főként, mivel az ország jogrendszerének részét képezik az egyezmények és a különböző szerződések is, mégis az alkotmény nem teszi lehetővé a lakosság közel 10 \%-át kitevő nemzeti kisebbségek (zsidók, „jugoszlávok", romák stb.) számára az államfői, az országgyülési képviselői stb. tisztségek elnyerését. ${ }^{39}$

Erre Dervo Sejdić és Jakob Finci egy boszniai roma, illetve egy zsidó férfi már 2006-ban felhívta a nemzetközi közösség figyelmét. Az Európa Tanács égisze alatt müködő Emberi Jogok Európai Bíróságához fordultak azzal a panasszal, hogy országuk alkotmánya másodrendű állampolgárnak minősíti őket. A strasbourgi bíróság ítéletében Sejdićnek és Fincinek adott igazat, az EU pedig azt várja BoszniaHercegovinától, hogy szüntesse meg a diszkriminációt. ${ }^{40}$ Az ország

\footnotetext{
${ }^{38}$ Ustav Bosne i Hercegovine.

http://www.mvp.gov.ba/dobro_dosli_u_bih/drzavno_uredjenje/ustav_bih/?id=261 BoszniaHercegovina alkotmánya. Član IV. Parlamentarna skupština.

${ }^{39}$ Bosznia-Hercegovinában a három államalkotó nemzet közül a bosnyákok száma meghaladta a 40\%-ot, a horvátoké pedig mindössze $17 \%$ körüli, mégis elvileg azonos a jogállásuk (éppúgy, mint a lakosság egyharmadát kitevő szerbeké).

${ }^{40}$ Sejdić and Finci v. Bosnia and Herzegovina (no. 27996/06)

http://echr.coe.int/Pages/home.aspx?p=hearings\&w=2799606_03062009\&language=lang. Letöttve: 2011. VI. 15.
} 
müködőképességéről sokat elárul az a tény, hogy a mai napig nem szerzett érvényt a fenti ítéletnek.

Szerbia alkotmánya egyéni és kollektív jogokat ír elő a kisebbségeknek, és tiltja a velük szembeni diszkriminációt. Tilos az erőszakos asszimiláció és a kisebbségiek által lakott területek nemzetiségi összetételének megváltoztatása. Habár nem biztosítja a kisebbségek országgyűlési képviseletet, mégis új intézményként jelent meg 2006-ban a nemzeti tanács intézménye, amelynek hatásköre a kulturális autonómia, vagy a perszonális autonómia alá tartozó négy területet öleli fel. Ezek: a nyelvhasználat, az anyanyelvi oktatás, a művelődés és a kulturális hagyaték őrzése, továbbfejlesztése, valamint az anyanyelvü tájékoztatás (Szerbia alkotmánya, 75. §). Tíz nemzeti kisebbség - bolgár, bosnyák, bunyevác, horvát, magyar, roma, román, rutén, szlovák, ukrán - hozta létre a nemzeti tanácsot, amely a hatóságokkal együttmúködve oldja meg a felmerült problémákat.

A nemzeti kisebbséghez tartozó személyek jogosultak egyforma feltételek szerint hivatalnoki és vezető tisztségeket betölteni. ${ }^{41}$ A nemzeti kisebbségek számára 2004 óta a jogrend lehetővé teszi, hogy a részarányos választási rendszer alapján zajló választásokon nem kell átlépniük az ötszázalékos parlamenti küszöböt. Erre nem is lennének képesek sem önállóan, sem másik kisebbségi párttal megkötött koalícióban, ezért esetükben az úgynevezett természetes küszöböt alkalmazzák. A 250 népképviselőből álló országgyűlésbe így a kisebbségi pártok kedvezményesebb módon juthatnak be, mint az országos listákat benyújtó politikai pártok. Az egy mandátum elnyeréséhez szükséges szavazatmennyiség kiszámítása akként történik, hogy a mandátumot eredményező szavazatok számát elosztják az összes kiosztható mandátumok számával (250-el). ${ }^{42}$

A választási törvény elöírja, hogy a "nemzeti kisebbségi politikai párt olyan politikai párt, melynek alapcélja a nemzeti kisebbség képviselete, jogainak védelme és javítása a nemzetközi sztenderdekkel összhangban". ${ }^{43}$ Az Állami Választási Bizottság dönt arról, hogy az adott pártlista benyújtója valójában egy nemzeti kisebbségi politikai párt státuszával rendelkezik-e.

A fenti modell értelmében 2014-ben az 53,12 \%-os (3 574003 fö) részvételnél a Vajdasági Magyar Szövetség (VMSZ) a szavazatok 2,1\%-ával (75.248 szavazattal)

${ }^{41}$ Az államigazgatási, közszolgálati, autonóm tartományi szervekben és a helyi önkormányzatoknál dolgozók arányának meg kell felelnie a nemzetiségek országos számarányával, azaz a kisebbségieknek arányos részvételt kell biztosítani a hivataloknál.

42 Horváth László: Parlamenti választások Szerbiában, Montenegróban és Macedóniában. In: Parlamenti Szemle. 2017/1. $\quad$ pp. 95-111. https://parlamentiszemle.hu/wpcontent/uploads/2017/10/parlamentiszemle-parlamentiszemle.hu-20171-lapszam-horvath-laszlo.pdf. Letöltve: 2020. január 2.

43 Zakon o izboru narodnih poslanika (Službeni glasnik RS", br. 35/00, 57/03 - odluka Ustavnog suda 72/03 - dr. zakon, 75/2003 - ispr. dr. zakona, 18/04, 85/05 - dr. zakonik, 101/05 - dr. zakon, 85/2005 - dr. zakon, 104/09 - dr. zakon, 28/11 - odluka Ustavnog suda 36/11). http://www.rik.parlament.gov.rs/doc/dokumenta/zakoni/ZoINP/zakon\%200\%20izboru\%20narodnih\% 20poslanika.pdf. Letöltve: 2020. január 2. 
hat mandátumot szerzett és így önálló parlamenti frakciót alapíthatott (minimum ötfösek a szerbiai frakciók). ${ }^{44}$

A 2016. április 24-én lebonyolított választásokon a VMSZ négy mandátumot nyert el, ezen kívül pedig még négy kisebbségi lista jelöltjei is bejutottak a parlamentbe, mégpedig a Szandzsáki Bosnyákok Demokratikus Közössége és a Szandzsáki Demokratikus Akciópárt két-két, a Zöld Párt és a Demokratikus Cselekvés Pártja egyegy mandátumot szerzett. ${ }^{45} \mathrm{~A}$ VMSZ is tagja a Kárpát-medencei Magyar Képviselők Fórumának (KMKF).

A 2020-as választásokon a képviselőházba négy nemzeti kisebbségi listáról kerültek be képviselők. A VMSZ az eddigi négy helyett kilenc képviselővel rendelkezik. Az albán kisebbségnek 3, két bosnyák kisebbségi pártnak pedig szintén 3, illetve 4 képviselője van.

Montenegróban az általános jogok és szabadságjogok mellett a nemzeti és etnikai közösségeknek joguk van a saját anyanyelvükön való oktatásra, valamint az információk megismerésére, továbbá az oktatási, kulturális és vallási egyesületek létrehozására, amelyeket az állam anyagilag támogat. Az alkotmány nem garantálja a nemzeti kisebbségek országgyülési képviseletét. Ehelyett biztosítja az "autentikus képviseletét" a parlamentben és a helyi képviseleti szerveknél, valamint az arányos képviseletét a közhivatalokban, az állami hivatalokban és a helyi önkormányzatoknál. 46

Az alternatív választási küszöb alapján a kisebbségi közösségek választási listája kedvezményes módon juthat be a parlamentbe. A legkisebb délszláv országban a nemzetiségi kérdés igen bonyolult, ugyanis a montenegróiak majdnem 29\%-a magát szerbnek tartja, 45\%-a pedig montenegróinak, így a nemzeti kisebbségeknek (8,5\% bosnyák, $5 \%$ albán, $3 \%$ muzulmán, $1-1 \%$ roma és horvát) döntő szerepe volt az ország függetlenségének kiharcolásában, ahogy annak megtartásában is. Nélkülük nem lehetséges parlamenti többség sem. 2020-ban a 81 fös parlamentben a szocialista-liberális kormány elveszítette a 42 fös szúk többségét, amelynek szerves része volt a négy kisebbségi (két bosnyák és egy-egy albán, illetve horvát) képviselő. A horvátok azonban pár héttel a választás előtt egy új pártot alapítottak, így szavazataik megoszlottak a két lista között, így egyik sem érte el a 0,35\%-os küszöböt. Ezért jelenleg nincs parlamenti képviselőjük. A Szerbiához közel álló, eddig ellenzékben lévő párt mégsem tudott kormányt alakítani az egyik albán párt, a polgári Egyesült reformakció nélkül.

Macedóniában a lakosság egyharmadát kitevő albánoknak és a többi kisebbségnek igen széles körüjogaik vannak. Az albán-macedón konfliktus lezárását szolgáló 2001. évi alkotmánymódosítás szerint a macedón nyelv és a cirill írás mellett az egész ország területén hivatalos lett az albán nyelv és a latin írás is. ${ }^{47}$ Ezenkívül az albánok jogot kaptak az anyanyelvükön kiadott személyi okmányokra, és az

\footnotetext{
${ }^{44}$ Bálint Csaba: Szerbia választott, a Vajdasági Magyar Szövetség hat mandátummal frakciót alakithat. In: Barankovics Alapítvány. https://barankovics.hu/cikk/jatekon-kivul/szerbia-valasztott-a-vajdasagimagyar-szovetseg-hat-mandatummal-frakciot-alakithat. Letöltve: 2020, január 2.

45 Horváth i. m.

${ }^{46}$ Ustav Crne Gore. Službeni list Crne Gore, br. 1/2007. Zaštita identiteta. Član 79.

${ }^{47}$ Az alkotmány formulációja szerint "az a nyelv és írás, amelyet a lakosság 20\%-át kitevő állampolgárok használnak". Lásd Амандман VI. на Уставот на Република Македонија.
} 
arányos képviseletükre valamennyi intézményben. 2019-ben újabb engedményként az albán nyelv hivatalos lett az egész ország területén. Erre még a továbbiakban egy külön fejezetben térek ki.

A 2008. február 17-én függetlenné vált Koszovói Köztársaság Nemzetgyűlése 120 képviselőből áll, akik közül legalább húsz mandátum biztosított a kisebbségek számára. ${ }^{48}$ Ezek közül legalább tíz képviselőhely illeti a szerb, három a bosnyák, kettő a török, illetve egy-egy a roma, az askali, az egyiptomi és a goráni kisebbségeket, valamint további egy mandátum a romák, az askalik és az egyiptomiak azon képviselőjét, akinek a listája a legtöbb szavazatot kapta (63-64. §). ${ }^{49}$ Erre az elosztásra akkor kerül sor, ha valamelyik kisebbség egyébként nem kapná meg az elvárható képviseletet. Nyilvánvalóan a szerbekre gondolt az alkotmányozó, mivel javarészük nem ismeri el az államot, így a választásokon sem vesz részt, ahogyan a népszámlálást is bojkottálták.

Az alkotmány a kisebbség szó helyett a közösség kifejezést használja, egyértelmüen azzal a szándékkal, hogy ne sértse meg azon szerbeket, akiknek Koszovó máig erősen fájó seb. Megjegyzendő még, hogy a parlament öt alelnöke közül kettő a nemzeti közösségek soraiból került ki, az egyik közülük szerb. Koszovónak két hivatalos nyelve van: az albán és a szerb, míg a török, a bosnyák és a roma nyelvek járási szinten hivatalosak, illetve a törvénnyel összhangban használhatók országos szinten is (5. §).

Bosznia-Hercegovinához hasonlóan, Koszovóban is erős a nemzetközi közösség jelenléte. A Nemzetközi Polgári Képviselőnek hasonló jogosítványai vannak, mint Bosznia-Hercegovinában a fömegbízottnak (High Representative). ${ }^{50}$

Bulgáriában a nemzeti kisebbségek számára engedélyezettek az őket általánosan megillető szabadságjogok, emellett az országban fontos politikai tényező a muszlimokat (török, pomák, roma) képviselő Mozgalom a jogokért és szabadságjogokért nevü politikai szervezet. ${ }^{51}$

\section{Kitekintés az Európai Unió tagállamainak szabályozására}

Mint láttuk a déli szomszédainknál a kisebbségek parlamenti képviseletének bevezetése a nemzetközi elismerés kivívása vagy az EU-hoz való csatalakozás

\footnotetext{
${ }^{48}$ Ustav Republike Kosovo - Kushtetuta e Kosovës http://www.kushtetutakosoves.info/repository/docs/Ustav.Republike.Kosovo.bosanski.pdf

${ }^{49} \mathrm{Az}$ Askalik az albán nyelvet beszélő muszlim vallású albánosodott romák, akik vélhetően Palesztinából származnak és nevüket az izraeli Ashkelon varosról kapták. Az Egyiptomiak is az albán nyelvet beszélő muszlim vallású albánosodott romák, akik vélhetően Egyiptomból származnak. A Goranik a Gora térségben - Koszovó-Albánia és Macedónia határain - elszigetelten élő iszlám vallású délszláv etnikai csoport, amely a macedón és ószerb nyelvhez hasonló nyelvjárást beszéli. Mindhárom etnikumot Szerbia külön nemzetként ismerte el.

${ }^{50}$ Heka László: A szláv államok jogrendszerei. JATEPress - Szegedi Egyetemi Kiadó, Szeged, 2008, 107. p.

51 Конституция на Република България „Държавен вестник" 6р. 56 от 13.07.1991 г., в сила т 13.07.1991 г., изм. и доп., бр. 85 от 26.09.2003 г. изм. и доп., ДВ. бр.18 от 25.02.2005 г., бр. 27 от 31.03.2006 г., бр.78 от 26.09.2006 г. - Решение № 7 на Конституционния съд от 2006 г., бр. 12 от 6.02.2007 г.) (ДВ, бр. 12 от 6 февруари 2007 г.).
} 
érdekében történt. Ez önmagában nem nemzetközi kötelezettség, ennek ellenére több országban is található olyan intézményi megoldás, mely a kisebbségek képviseletét hivatott előmozdítani. Magyarországon a 2011. évi CCIII. törvény az országgyülési képviselők választásáról tette lehetővé a nemzetiségek (már nem nemzeti kisebbségeknek nevezi őket a törvény) parlamenti képviseletét. Az a 2014. évi parlamenti választások óta biztosított, hogy a tizenhárom törvényben elismert nemzetiség kedvezményes mandátumot szerezhet (ha kellően nagy létszámmal rendelkeznek), vagy ennek hiányában nemzetiségi szószólót delegálhatnak az Országgyülésbe. ${ }^{52}$

Kedvezményes mandátumra jogosultak a nemzetiségi listák, „ha megszerzik az országos listákra leadott, illetve azokhoz hozzászámolt töredékszavazatok összesített száma 93-ad részének egynegyedét." ${ }^{153}$

2014-ben a kedvezményes kvóta eléréséhez 20022 szavazatra volt szükség egy adott nemzetiségnek, amit még a két nemzetiség, a német és a roma nemzetiség sem tudta elérni. Ezért az első ciklusban a nemzetiségi szószólók képviselték a adott kisebbséget, akiknek a jogaik természetesen korlátozottabbak, mint az országgyülési képviselőké. ${ }^{44}$ 2018-ban a Magyarországi Németek Országos Önkormányzata 26.477 érvényes szavazattal egy kedvezményes mandátumban részesült. ${ }^{55}$

Az EU-ban Horvátországon és Szlovénián kívül további kilenc országban létezik valamilyen típusú nemzeti kisebbségi képviselet. Belgiumban (egy felsőházi) és Cipruson területi-etnikai alapon jár a képviseleti jog ${ }^{56}$, Dániában ${ }^{57}$, Finnországban (az Eduskunta 200 képviselője közül egyet a többségében svéd anyanyelvűek lakta

${ }^{52}$ Erről lásd inter alia: Kovács Péter: A kisebbségek parlamenti képviselete - nemzetközi kitekintésben. In: Kisebbségkutatás 2014/1. pp. 15-29.; Kuruczi Gábor: A nemzetiségek parlamenti képviseletének kérdéséről. In: Pázmány Law Working Papers 2013/14.; Móré Sándor: A nemzetiségi szószólói intézmény jogi kerete és működésének első két éve. 2016 In: Parlamenti Szem/e 2016/2. pp. 30/51.; Szabó Zsolt: A nemzetiségi szószólók. In: Karsai, József (szerk.): A képviselók és a nemzetiségi szószólók jogállása és javadalmazása, Országgyűlés Hivatala. Budapest, 2014., pp. 49-52.; Tar Ferenc (2015): Képviselők vagy szószólók? - Kisebbségi képviselőválasztás Magyarországon. In: Modern Geográfia 2015/II. pp. 25-40.

53 Kurunczi Gábor: Az általános és egyenlő választójog elvével összefüggő kihívások alkotmányjogi elemzése a magyar szabályozás tükrében. Doktori értekezés. Budapest 2019. 107. p. https://jak.ppke.hu/uploads/articles/12332/file/Kurunczi_G\%C3\%A1bor_dolgozatv.pdf

${ }^{54}$ A szószólók jogait és kötelezettségeit tartalmazza a Nemzetiségek jogairól szóló 2011. évi CLXXIX. törvény, valamint az Országgyülésröl szóló 2012. évi XXXVI. törvény és az Egyes házszabályi rendelkezésekröl szóló 10/2014. (II. 24.) Országgyülési határozat. is biztosítja.

55 Nemzeti Választási Iroda https://www.valasztas.hu/orszagos-listakeredmenye?p_p_id=ogylistaseredmenyadatlap_WAR_nvinvrportlet\&p_p_lifecycle $=0 \& p \_p \_s t a t e=n o r m$ al\&p_p_mode=view\&p_p_col_id=column-

2\&p_p_col_pos=1\&p_p_col_count=2\&_ogylistaseredmenyadatlap_WAR_nvinvrportlet_tabId =tab2

${ }^{56}$ A ciprusi Vouli Ton Antiprosópon nevú parlament 1985-től 80 képviselőből áll, kik közül 56 tagot (70\%ot) adott a görög és 24-et (30\%-ot) a török ciprióta közösség. Az etnikai konfliktusok miatt a megosztott országban a török ciprióták számára fenntartott helyek 1963 óta betöltetlenek. Három képviselő (vagyis a mandátumok $10 \%$-át) az örmény, a maronita és a katolikus vallású kisebbségiek sorából kerül ki.

${ }^{57}$ A Fölketing nevű parlament 179 képviselőjéből 2-2 föt a dán fennhatóság alá tartozó autonóm Grönland (2 166086 km² területü, ám mindössze 56 ezer fös szigete), illetve az alig 50 ezer fös Feröer-szigetek (pontosabban annak Løgting nevű parlamentje) delegálnak. 
autonóm Aaland-szigetek adja, ${ }^{58}$ valamint a számiknak saját kulturális önkormányzatuk - Saamelaiskäräjät - van, melynek 11, többek között nyelvi, bányászati, erdészeti és oktatási jogosultságai vannak ${ }^{59}$ ) és az olasz Szenátusban a zömében kisebbségek által lakott területeken külön választókerületekben választják a gyakran a kisebbséghez tartozó képviselöt. Végül egyfajta képviselet biztosítása történhet az alacsonyabb vagy kedvezményes választási küszöb elörrásával. Magyarország, Olaszország (képviselőház)60, Románia (alsóház), valamint Lengyelország esetében ez a választási küszöb meghatározásának a hiányával valósul meg.

Valójában a horvátok és a szlovénok mellett csupán a belgák, a dánok és a finnek biztosítják a kisebbségi képviseletet. A két jugoszláv utódállam megoldása azonban eltér a többitől, mivel esetükben konkrét kisebbségeknek garantálja a képviseletet, míg a belgák, a dánok és a finnek egyes területeinek képviselői kapnak mandátumot a parlamentben.

Lengyelországban a nemzeti és etnikai kisebbségekről és a regionális nyelvekről szóló 2005, január 6-ai törvény kilenc kisebbséget sorol fel taxatíve Ezek: a fehérorosz, a cseh, a litván, a német, az örmény, az orosz, a szlovák, az ukrán és a zsidó. ${ }^{61} \mathrm{~A}$ Sejmbe történő választásnál a kisebbségi jelölteknek nem kell elérni az öt százalékos küszöböt (ennek köszönhetően a német kisebbség az utóbbi években megválaszthatja a képviselőjét). ${ }^{62}$

Spanyolországban az Autonóm Közösségek egy-egy szenátort küldhetnek a felsőházba és további egy szenátort minden területükön élő egymillió lakos után. A francia Assemblee Nationale és a luxemburgi Chambre des Députés nem ismerik a nemzeti kisebbségek intézményét, ahogy Görögország sem. Ez utóbbiban csak nyelvi-vallási kisebbségek léteznek, akik a Vouli ton Ellinon nevü parlamentben éppúgy választanak képviselőt, mint bármelyik más állampolgár. ${ }^{63}$ Jelenleg három

${ }^{58}$ Åland-szigetek mintegy háromszáz lakható szigetből álló, zömében svéd anyanyelvű lakosságból tevődik össze. Lásd: Summers, James J.: The Right of Self-Determination and Nationalism. In: International Law - International Journal on Minority and Group Rights, 12/2005. 344. p.

${ }^{59}$ Saamelaiskäräjät https://www.samediggi.fi/lautakunnat/elinkeino-ja-oikeus/lainsaadanto/

${ }^{60}$ Olaszországban a nemzeti kisebbségeknek kijár a védelem, de a kétkamarás (Camera dei deputati és a Senato della Repubblica) országgyúlésben mindenki az egész "nemzetet" képviseli (az Alkotmány 67. §). Azonban a Rosatellum néven ismert 2017/165-ös választási törvény (Modifiche al sistema di elezione della Camera dei deputati e del Senato della Repubblica. Delega al Governo per la determinazione dei collegi elettorali uninominali e plurinominali. 17 G00175 GU Serie Generale n.264 del 11-11-2017. LEGGE 3 novembre 2017, n. 165. https://www.gazzettaufficiale.it/eli/id/2017/11/11/17G00175/sg) egyes rendelkezések elősegítik a kisebbségi lakosságú régiók képviselőinek vagy szenátorainak megválasztását. Ilyen például a németek lakta Bolzano tartományra vonatkozó szabályozás. A képviselőházi választásoknál az elismert nyelvi kisebbségek regionális listái (Trentino Alto-Adige, FriuliVenezia Giulia, Valle d'Aosta, Szardínia, Szicília térségben) kedvezőbb elbírálás alá esnek.

61 Ustawa o mniejszościach narodowych i etnicznych oraz o języku regionalnym. Dz.U.2017.0.823 t.j. Ustawa z dnia 6 stycznia 2005 r. o mniejszościach narodowych i etnicznych oraz o języku regionalnym. Art. 2.

62 Konstytucja Rzeczypospolitej Polskiej z dnia 2 kwietnia 1997 roku. (Dz.U. z dnia 16 lipca 1997 r., nr 78, poz. 483, sprost.: z 2001 r. Nr 28, poz. 319).

${ }_{63}$ Forrás: Europski centar za parlamentarna istraživanja i dokumentaciju. Izvor: Narod.hr/lesar.info/hrvatski-fokus.hr http://www.scribd.com/doc/252497720/Prava-Predstavnika-Nacionalnih-Manjina-u-ParlamentimaSa\%C5\%BEetak-Odgovora. 
trákiai muszlim tagja van a 300 fős parlamentnek. Számunkra különösen érdekes a román törvényhozás összetétele.

A román alkotmány elismeri és biztosítja a nemzeti kisebbségekhez tartozó személyek jogát az etnikai, kulturális, nyelvi és vallási identitásuk megőrzéséhez, fejlesztéséhez és kifejezéséhez (6. §) ${ }^{64}$ A választási rendszer 2015-ös átalakítása után a kétkamarás parlamentben 312 képviselői, illetve 136 szenátori mandátum mellett 18 nemzeti kisebbségi szervezet kedvezményes módon juttathat egy-egy parlamenti képviselőt a törvényhozásba. ${ }^{65}$ Ez azt jelenti, hogy egy-egy mandátumhoz jutnak a nemzeti kisebbségekhez tartozó listák akkor is, ha nem érik el az öt százalékos választási küszöböt, de legalább négy megyében megkapják a szavazatok húsz százalékát. A gyakorlatban ez a rendelkezés csupán a Romániai Magyar Demokrata Szövetség (RMDSZ) számára jelentett biztos parlamenti jelenlétet. ${ }^{66}$

Horvátországhoz hasonlóan a külhoni románok külön választókerületben választanak négy képviselőt és két szenátort. Az ország 41 megyéje mellett Bukarest külön választókerületet képez, míg a külföldön élő románok számára egy 43. választókerületet alakítottak.

\section{Horvátország, Macedónia és Bulgária esete}

Jóllehet az alkotmányban és törvényekben rögzített kisebbségi jogok vitathatatlanok, mégis a kisebbségi képviselők gyakran komoly megpróbáltatásoknak vannak kitéve. E rövid kitekintésben Horvátország, Észak-Macedónia és Bulgária parlamentjeit vesszük górcső alá.

A horvátoknál a parlamenttel kapcsolatos problémák a 2015. november 8-án megtartott választások után jelentkeztek. 2016. január 22-én a kormányzó HDZ szövetségese lett a három évvel korábban megalakult Most (Híd) - a független képviselők szövetsége, de a közös kormányzás rövid időtartamú volt. Az előrehozott választásokat 2016. október 10-11-én tartották meg, és ismét ez a két párt alakíthatott kormányt. Az újabb szakítás után a HDZ a liberálisokkal és a kisebbségekkel alakított kormányt. A nacionalisták számára a legnagyobb "gondot" a Szerb Demokratikus Önálló Párt (SDSS) három képviselőjének kulcsszerepe jelentett, mert nélkülük a kormánynak nem volt meg a szükséges többsége. ${ }^{67}$ Ezért

http://www.hrvatski-fokus.hr/index.php/najnovije-vijesti/15215-prava-predstavnika-nacionalnihmanjina-u-europskim-saborima. Izvor: Narod.hr/lesar.info/hrvatski-fokus.hr

${ }^{64}$ Románia Alkotmánya. 62. §.

http://jog.sapientia.ro/data/hallgatok/letoltesek/Romania_alkotmanya_HU.pdf. Letöltve: 2020. január 2.

${ }^{65} \mathrm{Az}$ új rendszerben csökkent a képviselők száma: a korábbi 588 mandátum helyett azóta 466 mandátum osztható ki a törvényhozó testületben, vagyis átlagban 73 ezer emberre választanak egy képviselőházi tagot és 168 ezer emberre egy szenátort.

${ }^{66}$ Fábián Gyula: A nemzeti kisebbségi jogok biztosításának alakulása Romániában 1918-2018, avagy „A gyulafehérvári ígéretek megtagadásától a Minority SafePack ellenzéséig - 100 év romániai kisebbségjogi történet". Acta Universitatis Sapiantiae, Legal Studies, 7, 2 (2018) 165-261. 227. p.

${ }^{67} \mathrm{~A}$ jobboldal a fenti két pártnak felrója a "honvédelmi háborúval" kapcsolatos eltérő álláspontját, hogy Vukovárban cirill feliratú táblákat akarnak kihelyezni, továbbá a nemzeti öntudat hiányát stb. Az ellenük 
a kisebbségek ellen két sikertelen népszavazást kíséreltek megvalósítani, azzal a céllal, hogy a kisebbségi képviselők ne szavazhassanak a kormányalakításról. ${ }^{68} \mathrm{~A}$ 2020-as választásokon a HDZ a szövetségeseivel együtt 68 mandátumhoz jutott, így a nyolc kisebbségi képviselővel ismét kormányzati pozícióba került a jobboldaliak nagy elégedetlenségére.

A 2019. február 12-e óta Észak-Macedónia név alatt ismert jugoszláv utódállam az ország létrehozásának pillanatától számos problémával szembesült. Elsőként a görögök kifogásolták az ország nevét, a bolgárok pedig nem ritkán a macedónokat bolgároknak nevezik, ahogy a nyelvüket is. Emellett az albán kisebbség folyamatosan követelte jogainak megerősítését.

A 2016-ban megtartott választásokon a relatív győztes 454577 szavazattal (39,39\%) a nemzeti-konzervatív Belső Macedón Forradalmi Szervezet - Macedón Nemzeti Egység Demokratikus Pártja (VMRO-DPMNE) koalíció volt, amely 51 mandátumot kapott (magának a pártnak 39 képviselőhely jutott). A köztársasági elnök a VMRO-DPMNE vezetőjét, Nikola Gruevskit bízta meg a kormányalakítással. Neki azonban nem sikerült az előírt húsz napon belül megállapodni a korábbi, 2008 és 2016 közötti szövetségesével, a Demokratikus Integrációs Unióval, amely a legnagyobb albán párt.

Az albán pártok ugyanis egy közös nyilatkozatban követelték az albán nyelv hivatalos elismerését, amit a VMRO-DPMNE nem tudott támogatni. Ezután a Macedóniai Szociáldemokraták Szövetségének (SDSM) elnöke, Zoran Zaev kapta meg az államföi megbízatást. A szociáldemokraták és koalíciós partnerei 436981 (37,81\%) szavazattal és 49 mandátummal rendelkeztek a Sobranie nevü országgyülésben. Zaev megegyezett az albán pártokkal - a Demokratikus Integrációs Unióval (DUI), amely tíz képviselő helyet kapott, továbbá az Alternativa nevü háromfós albán blokkal (a Besa-párt többsége), és az SDSM tradicionális szövetségeseivel az Albánok Demokratikus Pártjával (DPA), amely két képviselővel rendelkezik. A parlamenti többséget egy-egy képviselővel biztosítja még a Macedóniai Romák Szövetsége és a Török Demokrata Párt. A köztársasági elnök, Đorgo Ivanov azonban nem akarta megbízni Zaevet a kormányalakítással, mivel az bejelentette az albán nyelv egyenrangúságát. ${ }^{69}$ Végül április 27 -én megalakult a Sobranie, amely elnökének a DUI jelöltjét Talat Xhaferit (ejtsd Dzsaferi) választotta meg. Ekkor törtek be az épületbe a tiltakozó jobboldali aktivisták, akik megtámadták a képviselőket. 70 állampolgár, 22 rendőr és három képviselő szorult orvosi segítségre, közülük az albán nemzetiségű képviselőt kórházba is kellett szállítani. Ezt követően 2017. május 31-én a Sobranie bizalmat szavazott az új kormánynak, amely a tizenöt albán képviselő nélkül nem müködhetne. Jóllehet az ellenzékben is található

irányuló támadás lényegében a HDZ mostani vezetőségére irányul, amelyet még a párt szavazóinak egy része is "baloldali elhajlásokkal" vádolja.

${ }^{68} \mathrm{U}$ ime obitelji: Nije dobro da manjina određuje premijera i Vladu. In: Direktno.hr. 2017. 09. 19. https://direktno.hr/domovina/u-ime-obitelji-nije-dobro-da-manjina-odreduje-premijera-i-vladu-98276/. Letöltve: 2020. I. 7.; Željka Godeč: Burne reakcije nakon inicijative udruge "U ime obitelji" 'Taj referendum je totalitaran, HDZ se od njega mora ograditi!' In: Jutarnji list Zagreb, 2018. 05. 01. https://www.jutarnji.hr/vijesti/hrvatska/burne-reakcije-nakon-inicijative-udruge-u-ime-obitelji-tajreferendum-je-totalitaran-hdz-se-od-njega-mora-ograditi/7306549/. Letöltve: 2020. I. 7.

69 "Иванов не му го дава мандатот на Заев". Дојче Веле. 1 март 2017. конс. 28 април 2017. 
két albán párt - az Albánok Szövetsége három és a Besa két képviselővel - mégis az elégedetlenek a kormányon lévőket bírálják a hazaszeretet hiánya miatt. A közel három évtizedig tartó görög-macedón probléma is megoldásra került, amely a két ország között 2018. június 17-én aláírt kompromisszumos megállapodás (Prespanski dogovor) aláírásával kezdődött. Ezt követően a macedón parlament 2019. január 11én kétharmados többséggel elfogadta az ország nevének megváltoztatásáról szóló alkotmánymódosítási javaslatot (a 120 tagú Sobranie 81 képviselője szavazott igennel a javaslatra, a VMRO-DPMNE pedig bojkottálta az ülést.) ${ }^{70}$

Végül a parlament elfogadta a hivatalos nyelvről szóló törvényt, amely a macedón mellett az albánt is hivatalos nyelvvé tette. Ez újabb komoly nézeteltéréseket eredményezett. $^{71} 2019$ januárjában Đorgo Ivanov köztársasági elnök nem volt hajlandó másodjára sem aláírni, mert alkotmányellenesnek minősítette. ${ }^{72}$ Végül azt az országgyülés elnökének aláírásával kihirdették a hivatalos közlönyben (Службен весник на Република Македонија). ${ }^{73}$

A VMRO-DPMNE ezután az alkotmánybírósághoz fordult kifogást emelve a törvény hatályba lépése miatt az államfő aláirásának hiányában. ${ }^{74} \mathrm{~A}$ nemzeti oldalnak különösen az "fáj", hogy ezután az országgyülés elnöke az üléseket akár albán nyelven is vezetheti. Az alkotmánybíróság több mint két év után tüzte ki 2021. március 18-án az előkészítő tárgyalást a Prespai Egyezmény és az albán nyelv hivatalossá tételéről szóló törvények ügyében. ${ }^{75} \mathrm{Az}$ alkotmánybíróság arra hivatkozott, hogy több alkotmányos panasz érkezett a 2019. év folyamán (A Levica és a VMRO-DPMNE politikai pártok mellett, a Macedónok Világkongresszusa, Solza Grceva és Tanja Karakamieševa professzorok, illetve több állampolgár részéről), így azokat egyesítették. ${ }^{76}$ Tekintettel arra, hogy időközben (2021. május 26-án) az alkotmánybíróság élére új elnököt választottak Dobrila Kacarska személyében (az alkotmánybíróság kilenc bírójából hatan szavaztak rá) ${ }^{77}$, és további bírók kinevezése

70 Hasonlóan szoros eredmény született a görög parlamentben is 2019. január 25-én a ratifikálási szavazásnál (153 képviselő igennel, 146 nemmel szavazott).

71 Sinisa Jakov Marusic: Северна Македонија: Законот за јазиците, повторно ги стави на тест меѓуетничките односи. In: Balkan Transitional Justice. https://balkaninsight.com/2019/12/30/северна-македонија-законот-за-јазици/?lang=mk. Letöltve: 2020. I. 8.

72 Albanski drugi službeni jezik u Makedoniji. http://balkans.aljazeera.net/vijesti/albanski-drugi-sluzbenijezik-u-makedoniji Letöltve: 2020. I. 8.

73 Dejan Saveski: Proceduralna neustavnost i nezakonitost Prespanskog sporazuma, Zbornik radova Pravnog fakulteta u Splitu 57 (4), Split, 2020, pp.1193-1225

74 Makedonska opozicija traži ukidanje Zakona o jezicima. In: Danas, Beograd. 2019. I. 19. https://www.danas.rs/svet/makedonska-opozicija-trazi-ukidanje-zakona-o-jezicima/: 2020. I. 8.

75 The Law on the Prespa Agreement and the Law on the Use of Languages before the Constitutional Court. In: Слободен печат. мк.

https://www.slobodenpecat.mk/en/zakonot-za-dogovorot-od-prespa-i-zakonot-za-upotreba-najaziczite-pred-ustavniot-sud/.

76 Уставниот суд расправа за Законот за Договорот од Преспа и за Законот за употреба на јазиците. In: $24 \mathrm{mk}$. https://24.mk/details/ustavniot-sud-rasprava-za-zakonot-za-dogovorot-od-prespa-i-zazakonot-za-upotreba-na-jazicite?fbclid=IwAR1tKzH8c-

HTDW1ZsvqgM2sGBW5W6YDp3URgGeFYszqZD7a1ZuRhLaBVXXM. Letöltve: 2021. június 9.

77 Judge Kacarska Appointed President of Constitutional Court. in: Skopje Diem. Macedonia in English. https://skopjediem.com/2021/05/27/judge-kacarska-appointed-president-of-constitutional-court/. 
is várat magára, így az ítélet megszületése várhatóan el fog húzódni. ${ }^{78} \mathrm{Az}$ alkotmánybíróság elnök asszonyának megválasztását egyébként az ellenzék nagy bizalmatlansággal fogadta, annál is inkább, mert a VMRO-DPMNE képviselői már tavaly novemberben Kacarska megválasztását a parlamentben (Sobranie) transzparensekkel és zajkeltéssel próbálták megakadályozni. ${ }^{79}$ Ez a bírónő volt annak a szkopjei bírói tanácsnak az elnöke, amely ítélkezett a 2017. április 27-én a parlament épületében elkövetett fizikai támadás ügyében. A tizenhat szabadságvesztésre ítélt személy között több VMRO-DPMNE-tag is volt, egyebek közt az akkori belügyminiszter, Mitko Cavkov is, akit „,az alkotmányos rend és a biztonság veszélyeztetése terrorista cselekmény elkövetésével" váddal 18 év szabadságvesztés büntetésre ítélt a bíróság. ${ }^{80}$ Igor Janušev a VMRO-DPMNE főtitkára igazságtalannak és politikailag elfogultnak nevezte az ítéletet. ${ }^{81} \mathrm{~A}$ konzervatívok tehát nem szívesen látták őt alkotmánybíróként, fél évvel később Kacarska már az $A B$ elnöke lett.

A fent elmondottak tükrében feltétlenül meg kell említeni Bulgária példáját is. Ott az ország lakosságának 12-13 \%-át kitevő muszlimok java része török nemzetiségü, de közöttük is akadnak az iszlám hitre áttért helyi keresztények leszármazottjai. Ezeket a volt Jugoszlávia területén bosnyákoknak nevezik (korábban muzulmán volt a nevük), a bolgárok viszont őket pomákoknak („помаци") hívják. Számuk a Balkánon eléri a félmilliót, ebből közel 300 ezren Bulgáriában, 150 ezren Törökországban élnek. ${ }^{82}$

A bolgárok szerint a pomák elnevezés a bolgár segíteni ("помara") szóból származik, mivel az iszlámra áttért bolgárok „kollaboránsként segítették a török hódítót". A rendszerváltás után a bulgáriai törökök és pomákok létrehozták a Mozgalom a Jogokért és Szabadságjogokért (Движение за права и свободи, DPS) nevú politikai tömörülést, amely az ország harmadik legerősebb politikai tényezőjeként képviseli a muszlimok etnikai vallási, kulturális és egyéb érdekeit. Ez a politikai tömörülés az 1991. évi választásokat követően a győztes Demokratikus Erő́k Uniójának koalíciós partnere lett, ami miatt a szocialisták az alkotmánybírósághoz fordultak.

Kérték a DPS betiltását és képviselői mandátumainak megsemmisítését, mert az alkotmány szerint „etnikai, faji vagy felekezeti alapon politikai párt nem hozható létre". Az alkotmánybíróság egyetlen szavazattal elutasította az indítványt azzal az indokolással, hogy a DPS nem politikai párt, hanem egy törvényesen bejegyzett

\footnotetext{
${ }^{78}$ Александар Димитриевски: Добрила Кацарска е нова претседателка на Уставниот суд. In: 360 степени. https://360stepeni.mk/dobrila-katsarska-e-nova-pretsedatelka-na-ustaven-sud/; Maksfaks: Судијката Добрила Кацарска е нова претседателка на Уставниот суд. In: Pravdiko. mk. https://www.pravdiko.mk/sudijkata-dobrila-katsarska-e-nova-pretsedatelka-na-ustavniot-sud/. Letöltve. 2021. június 9.

79 Александра М. Митевска: Пародија во собраниската сала: Вмровците свиркаат против изборот на Кацарска за уставна судијка. In: 360 степени. https://360stepeni.mk/parodija-vo-sobraniskatasala-vmrovtsite-svirkaat-protiv-izborot-na-katsarska-za-ustavna-sudijka/.

${ }^{80}$ Dominik Istrate: Court in North Macedonia jails former government officials over 2017 protests. In: Emerging Europe. 2019. march 19. https://emerging-europe.com/news/north-macedonian-court-jailsformer-government-officials-over-2017-protests/

$81 \mathrm{U} .0$.

82 Lásd Mario Apostolov: The Pomaks: A Religious Minority in the Balkans. Nationalities Papers 1996. 24(4), pp. 727-742.
} 
politikai tömörülés. Emellett pedig nem lehet betiltani egyetlen politikai szervezetet sem azon az alapon, hogy tagjainak zöme egy vallási vagy etnikai közösséghez tartozik. A DPS jelenleg 25 képviselőjével a 240 fös bolgár Nemzetgyűlésben (Народно събрание на Република България) ellenzékben van, így ezzel kapcsolatosan ideiglenesen nincsenek kisebbségi viták.

\section{Zárszó}

A nemzeti kisebbségek részvétele az állam ügyeinek intézésében különböző módon valósulhat meg. Európa volt szocialista országaiban a rendszerváltást követően ennek megvalósitása eltérő módon történt. Bebizonyosodott, hogy a rendszerváltás után az etnikailag homogénebb országok (Magyarország, Lengyelország, Csehország) könnyebben építették fel a demokratikus társadalmaikat, míg a soknemzetiségű országokban (posztjugoszláv utódállamok, Bulgária, Románia) széthúzás és nemzetiségü konfliktusok tapasztalhatók. Azokban, amelyekben nemzeti konfliktusok zajlottak, az állam igyekezett minél nagyobb mértékben integrálni a kisebbségeket, beleértve azt a nemzetiséget is, amely szembeszállt vele. Ezzel egyrészt megnyerte annak lojalitását és csökkentette a leendő újabb etnikai villongások lehetőségét. A jugoszláv utódállamok esetében erre szükség mutatkozott Horvátországban és Bosznia-Hercegovinában is, ahol a helyi szerbek nagy része nem volt hajlandó elismerni az új államok függetlenségét és azt sem, hogy ők azokban már nem az államalkotó nemzet részei, hanem nemzeti kisebbségek. Észak Macedóniában a kormánynak az albánok, Koszovóban pedig a szerbek bizalmát kell megnyernie. Szlovénia esete annyiban más, hogy a parlamenti képviseletet nem a két legnagyobb kisebbségnek - a szerbnek és a horvátnak - biztosította, hanem az őshonosnak nevezett magyar és olasz nemzetiségnek. Szerbia az egyetlen utódállam, amely Vajdaságban területi autonómiát ismer el az 1,2 milliós kisebbségben lévő nemzeteknek, akik képviseltetik magukat autonómiai és állami szinten egyaránt. A montenegróiak nemzetiségi kérdése is érdekesen alakul immár másfél évszázada. A tősgyökeres lakosság egyik fele magát szerbnek tartja, a másik (jelenleg többségben lévők) pedig montenegróinak. Mivel egyik félnek sincs abszolút többsége, így a kisebbségeknek döntő szerepe van az ország kormányzásában.

A kisebbségekkel szembeni magatartás, főleg a parlamenti képviselet garantálása tanúskodik az adott ország demokratizálásáról, illetve az európai sztenderdek tiszteletben tartásáról. Jóllehet a kisebbségi képviselet megadását a legtöbb ország jó szemmel nézi, mégis akadnak ellenlábasai is, akik felróják, hogy ezáltal sérül a választópolgárok egyenjogúsága, mely szerint egy választópolgárnak egy szavazatra van joga. Mivel a kisebbségek szavazhatnak az országos listára és a saját képviselőjükre is, ezért a bírálók úgy tartják, hogy ők emiatt többletjogokat kapnak. Ez egy olyan érv, amely növelheti a többségi nemzet és a kisebbségek közötti feszültségeket. Végső soron ez a társadalom dezintegrációjához vezethet.

Véleményem szerint a szerzett jogok esetleges megvonása, amit egyes horvát szervezetek indítványoznak, biztosan komoly feszültségeket okoznának és rossz hatással lennének a demokratikus intézmények erősítésére. Ugyanakkor célszerü 
átgondolni, hogy a parlamenti képviselet helyet valami más megoldással lehetne-e biztosítani a kisebbségek részvételét az ország ügyeinek intézésében. Elsősorban olyan megoldást kellene keresni, amellyel a kisebbségi jogaiknak biztosítását és védelmét kellő módon elláthassák, de a politikai csatározásokat elkerülhessék. Ezzel elháríthatnák azt a gyakori vádat, hogy az anyaországuk érdekeit képviselik, és nem azon államét, amelynek állampolgárai és megválasztott országgyűlési képviselői. 